\title{
Redistributive Politics in Russia: The Political Economy of Agricultural Subsidies
}

\author{
Vasyl Kvartiuk $^{1}$ (D) $\cdot$ Thomas Herzfeld $^{1,2}$
}

Published online: 14 August 2020

(c) The Author(s) 2020

\begin{abstract}
This paper explores whether redistributive politics can explain differences in agricultural subsidies in Russia, a country whose autocratic regime represents a fertile ground for strategic redistribution. Relying on political economy literature, we examine the strategies regional and federal Russian politicians utilize to allocate and distribute agricultural subsidies. Using unique 2008-2015 panel data, we test whether politicians target loyal or easily swayed voters and whether they use large farms as vote brokers. We find federal and regional politicians to allocate more agricultural subsidies when political competition against the dominant party is higher. Moreover, they appear to also target large farms for voter mobilization.
\end{abstract}

Keywords Agricultural subsidies · Redistribution · Political competition · Vote brokers · Russia

JEL Classification $\mathrm{D} 72 \cdot \mathrm{H} 77 \cdot \mathrm{H} 23 \cdot \mathrm{P} 16$

\section{Introduction}

Although Russia spends large amounts of resources to support its agricultural sector, not all farms benefit from these funds because allocation and distribution are highly unequal among the regions (Uzun 2005; Uzun et al. 2016). Russia's self-sufficiency doctrine ${ }^{1}$

\footnotetext{
${ }^{1}$ Russia's food self-sufficiency strategy was first adopted within the country's 2008-2012 State Program for Development of Agriculture and then developed further by the consequent program for 2013-2020.

Vasyl Kvartiuk

kvartiuk@iamo.de

Thomas Herzfeld

herzfeld@iamo.de

1 Leibniz-Institute of Agricultural Development in Transition Economies (IAMO), Theodor-Lieser-Str. 2, 06120 Halle (Saale), Germany

2 Martin-Luther-Universität Halle-Wittenberg, Universitätsplatz 10, 06108 Halle (Saale), Germany
} 
generates large political interest toward agriculture, with $0.93 \%$ of the country's GDP allocated toward direct and indirect support (OECD 2017). However, the regions benefit from these resources unequally since the composition of federal and regional ${ }^{2}$ cofunding differs greatly between the sub-federal units. Subsequently, subsidies per hectare vary substantially across sub-federal units: sometimes we observe 20 -fold differences. There could be two main reasons for these imbalances: first, because agricultural support is legally a primary responsibility of the regions (Shagaida et al. 2015) that have a substantial discretion in the size of the co-funding (Uzun et al. 2016), regional economic strength may affect the size of local co-funding. Second, although federal co-funding of agricultural subsidies is regulated by distribution formulas under the country's current legislation, ${ }^{3}$ de facto amounts may be substantially different (Frumina 2016). Controlling for the major variables in the distribution formulas and other agricultural economic factors, we still cannot fully explain the differences in agricultural subsidies.

In light of the growing scholarly interest in redistributive politics in Russia, this study draws upon political economy literature to analyze and further explain the subsidies' allocation and distribution. We examine how political incentives of central and regional politicians in Russia may affect the distribution of agricultural subsidies across and within the regions. A growing body of literature suggests that within the setting of a competitively autocratic Russian regime, political actors maximize their support by redistributing state resources (Popov 2004; Jarocińska 2010; Marques et al. 2016; Treisman 1998). However, all these scholars examine the motives behind the distribution of intergovernmental transfers to the regions. These analyses are lacking a more nuanced account of how Russian politics works with respect to concrete groups of voters and to the support for specific sectors. To our knowledge, this study is the first one to contribute to this body of literature by examining how central and regional governments appeal to a very important voter group: rural residents, who represent roughly one-third of the Russian population. Even though the agricultural sector employed about $7 \%$ of Russia's entire labor force in 2016 (RosStat 2017), agriculture is of central importance for rural residents and subsidies may affect the growth of their local agricultural sectors (Petrikov 2016; Uzun and Lerman 2017). Considering these circumstances, politicians may instrumentalize agricultural subsidies to reward or incentivize voters within a given sub-federal unit to support an incumbent political party. In particular, as "core voter" theory (Cox and McCubbins 1986) holds, incumbent politicians will transfer more resources to politically loyal voter groups. "Swing voter" theory (Dixit and Londregan 1996) describes another strategy, by which incumbents will target those groups of voters that are more likely to swing to, and vote for, their side. In other words, higher political competition may incentivize incumbents to cater to certain voter groups (Besley and Burgess 2002). Because Russian agricultural support involves relatively independent federal and regional co-funding components,

\footnotetext{
2 The Russian Federation is formed by 83 federal entities, such as oblasts, krais, republics and cities. Here, we use the terms "regions" as a synonym for these administrative units.

3 It would typically depend on local tax generation capacity, agricultural area, and some other more specific variables depending on the subsidy type.
} 
strategic redistribution may occur on both levels. In particular, federal politicians may target "core" or "swing" regions, whereas local politicians may be incentivized by the federal government to cater to local agricultural interests contingent on existing political competitors. Since Russia's current party in power, "United Russia" (UR), is highly hierarchical and well organized (Reuter 2010), the pressure from the party leaders may coerce regional representatives to maximize political support. Weingast (2009) argues that authoritarian regimes tend to make local elites dependent on transfers from the center to ensure that manipulating their size is an effective tool in controlling local elites.

Russian politicians may also have a strategy with respect to intra-regional distribution. Russia hosts some of the largest agricultural enterprises in the world, employing a substantial share of the rural labor force (Lerman 2017). This may have two implications for the politicians' strategies: first, considering Russia's experience of using employers as vote brokers (Frye et al. 2018), federal and local politicians may target large agricultural enterprises within their redistributive politics. Federal decision makers may see regions with predominantly large-scale agriculture as an attractive avenue for buying votes via manipulation with agricultural subsidies. Regionally, these enterprises may represent effective vehicles for voter mobilization for local politicians who are pressured via party hierarchies. Second, large agricultural businesses may be better organized and exert significant lobbying pressure. Following Olson's (1965) collective action theory, they have better administrative capacity and face lower transaction costs for engaging in lobbying activities in comparison with small producers.

To test our hypotheses, we use a unique 2008-2015 panel data set on federal and sub-federal shares of agricultural subsidies spent across 78 Russian regions. ${ }^{4}$ This allows us to follow two election cycles where the incumbent parties may have faced a dilemma to strategically distribute agricultural subsidies among the regions in order to maximize political support. Russia represents an interesting case since we observe a large variation among comparable regions in terms of the degree of political competition, farming modes and the amount of subsidies received. Because redistribution has been shown to be effective for voter mobilization in both democratic and autocratic settings (Stokes 2007), with its weak institutions, Russia's autocratic regime represents a fertile ground for redistributive politics.

In general, the evidence suggests that Russian politicians may be allocating and distributing agricultural subsidies with the end goal of maximizing their political support. In particular, we find evidence that the federal government targets those regions where the support for UR was lower in the past, while sub-federal politicians appear to be motivated to allocate more co-funding should they face larger political threats from local challengers. Regional governments appear to instrumentalize large agricultural enterprises as vote brokers.

\footnotetext{
${ }^{4}$ We exclude the regions of Khanty-Mansiyskiy, Yamalo-Nenetskiy and Nenetskiy, as well as the cities of Moscow and St. Petersburg, due to distortions in the agricultural sector and data availability.
} 


\section{Theoretical Framework}

In Russia, the allocation and distribution of agricultural subsidies follows a co-funding scheme from federal and regional budgets. At the federal level, the law stipulates a limited discretion over funds disbursement due to distribution formulas pertinent to each type of subsidies (e.g., crop, livestock, etc.). Regional politicians have much more discretion over the local co-funding since the law provides them with rough guidelines only. Despite these laws, both levels decide on their co-funding shares relatively independently and with substantial discretion. ${ }^{5}$ Consequently, we model total support allocation as a simultaneous game between the center and the regions with ex ante expectations of each other's contributions.

\section{Federal Allocation}

The rationale for using redistribution in a setting of political support maximization was formally developed by Shepsle and Weingast (1981) and further extended to incorporate different types of politicians' strategic behaviors by Cox and McCubbins (1986) and Lindbeck and Weibull (1987). Following the logic of this family of models, we assume a federal government that is exogenously incentivized to stay in office (office-seeking politicians) and is able to increase its chances by making a transfer to the regions in the form of co-funding within the agricultural support portfolio. We assume that the voters' utility is strictly positively related to these transfers together with consumption and ideological stands. As a result, the theory suggests that politicians can manipulate voters' decisions via transfers. Political science literature puts forth a debate about whether politicians will target their "core" supporters or the "swing" voters. Cox and McCubbins (1986) argue that political parties will prefer to reward their loyal supporters and not run the risk of appealing to the uncertain voters since they may not know their utility functions perfectly. On the other hand, Dixit and Londregan (1996) suggest that if the politicians can reasonably predict how many votes their transfers will buy, they will tend to prefer the voters with an uncertain ideological position, the "swing voters."

The discussion on "core versus swing" voter strategy is still ongoing, with existing empirical evidence for both the "core" (e.g., Hiskey 2003) and the "swing" voter theory (e.g., Dahlberg and Johansson 2002; Stokes 2005). More nuanced studies have also emerged focusing on the context of electoral competition. For instance, Aytaç (2014) finds that Turkish incumbent parties were directing resources to the districts with ideologically close challengers. On the other hand, Horowitz (2016) places ethnic diversity within Kenyan electoral districts as a factor that determines the targeting strategy. The evidence for the Russian context is not conclusive either. Popov (2004) and Jarocińska (2010) are among the scholars who find evidence that supports the "core voter" theory, as regions with a higher voting turnout for

\footnotetext{
5 Further details about the process of subsidy allocation and distribution can be found in "The Russian Context" section.
}

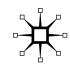


the ruling party enjoy more transfers from the federal government. Treisman (1998), on the other hand, finds that regions with more protests received more intergovernmental transfers. These hypotheses have never been tested within the case of Russian agricultural support distribution. We use a standard operationalization-winning margin with respect to the closest challenging party. If UR faced a serious competition in the region during previous elections, then the region can be considered a "swing" one. On the other hand, if the difference in a winning margin between the incumbent party and the closest challenger is large, we consider it a "core" region.

A key question that the politicians may be interested in is how effective redistributive politics are in transforming transfers into votes (Dixit and Londregan 1996). In other words, a decision-maker's problem is to identify a group of voters that would generate the greatest returns in terms of votes under minimal uncertainty. Poor voters appear to be a particularly attractive target for redistributive politics because marginal utility of income is higher for them (Dixit and Londregan 1998; Chubb 1982; Wilson and Banfield 1963; Brusco et al. 2004). An income gap between those working in agriculture and the rest of the economy in Russia makes its rural population a good candidate. ${ }^{6}$

A recent focus in the literature on redistributive politics is politicians' usage of vote brokers to help maximize political returns from transfers (Stokes 2005). Vote brokerage involves generating incentives for voters to vote for a certain candidate using coercion or in exchange for certain benefits (Rueda 2017; Gottlieb 2017; Mares and Young 2018). In particular, employers have been widely recognized to be effective vehicles for voter mobilization in developing (Baland and Robinson 2018) and developed contexts (Hertel-Fernandez 2016). In the Russian authoritarian context, Frye et al. (2018) find that workplace-based voter coercion works better than vote buying because vote buying is simply more expensive in the middle-income context. Large agricultural enterprises, as major employers in Russia's rural areas, may represent effective vote brokers because intimidation may be more effective with fewer local alternative employers. As a result, we expect large-scale agricultural production within a given region to facilitate the effect of federal-level strategic subsidies.

Apart from being vote brokers, large farms may generate enough political pressure in an attempt to maximize their receipt of agricultural subsidies. We model voters not as mere observers but as active participants in agricultural policy formation. Voter groups pursuing a certain common interest may actively invest resources trying to influence politicians in order to maximize transfer receipts (Becker 1983, 1985; Grossman and Helpman 1996). Accordingly, interest groups will exert pressure on the politicians hoping for returns in terms of transfers. Pressure effectiveness may be determined by the group size since smaller groups may have more capacity to deal with the "free-riders" (Olson 1965; Becker 1985). As a result, smaller groups may face lower transaction costs in exerting pressure. Our prediction is that regions with smaller number of larger farms should be successful in securing larger federal

\footnotetext{
${ }^{6}$ Average salaries in agriculture were close to $60 \%$ of the country-wide average during the years 2015-2017 (State Statistics Committee of Russia 2018).
} 
co-funding of agricultural subsidies. In addition, larger farms should have a capacity advantage in dealing with the bureaucratic burden of applying for subsidies.

\section{Regional Allocation}

Having less legal constraints for allocating shares of co-funding toward agricultural support, regional governments (just like their federal counterpart) may be driven by electoral incentives. Regional governments were found to be important gatekeepers for the center's redistributive politics (Albertus 2015). In Russia, local politicians may have incentives to maximize political support for the incumbent party in order to please the party leaders at the federal level (Ross 2010). In a centralized Russian context with a highly vertically integrated structure of UR, local governments may function as extensions of the central bureaucracy with vertical intra-party accountability (Jarocińska 2010). The success of local politicians is not measured by local economic indicators, but by the loyalty to UR (Konitzer-Smirnov 2005). Highly hierarchical party structure is designed to minimize a potential influence of regional elites and to effectively manage local politics from the federal level (Slider 2010). In an effort to maximize political support for UR regional politicians may have incentives to cater to certain interest groups, including agricultural ones, which could broker more votes in their favor. Local political competition may determine the extent of the pressure on local politicians to invest efforts in vote maximization (Hansen 1991; Grossman and Helpman 2001). As a result, relatively flexible agricultural subsidies may be instrumentalized to mobilize the voters from rural areas. In addition, local decision makers may use large farms within their constituencies as vote brokers just like their federal counterparts.

In a similar vein, the Cox-Meyerson framework (Cox 1987, 1990; Myerson 1993) explains why local politicians may target the agricultural sector instead of other industries in their effort to please federal party leaders. Following the framework, candidates maximize the support of their electorate by taking policy positions or promising policy benefits. Politicians rationally choose their positions considering the positions of other candidates. Cox's (1990) argument is that, in a proportional representation system like Russia's, the amount of votes needed to win will decrease as the number of competitors increases. Political actors will have incentives to appeal to smaller groups of constituents as the number of competitors rises, widening the ideological distance between the candidates. The model predicts that in the jurisdictions with high political competition, local politicians will cater more to narrow interest groups, like the farming community.

In consideration of Russia's political environment with its weak institutions, the literature related to government capture may be instrumental in explaining regional allocation of agricultural subsidies. Accordingly, Bardhan and Mookherjee (2000), extending a standard Grossman and Helpman (1996) framework, argue that, under certain conditions, local interest groups will be under higher uncertainty about which party to capture if no party is overwhelmingly supported ideologically and if the voters are more unpredictable in their voting behavior. This implies that farm interest groups will be reluctant to capture a regional political party (that, in turn, 
will be incentivized to allocate more agricultural subsidies) should it face a credible reelection threat. In this setting, traditional accountability to voters may be distorted by industry-specific interests. In particular, since local UR party organizations are extremely dependent on the federal level, there are nearly no accountability mechanisms to the regional inhabitants. With a minimal electoral threat from the voters, local politicians are prone to be captured by local interest groups (Bardhan and Mookherjee 2006). The only disciplining mechanism for local politicians and, as a result, the source of incentives to cater to local interest groups, is vertical party accountability: local UR leaders may risk their careers should they deliver unsatisfactory election outcomes.

\section{The Russian Context}

Russia's current agricultural support aggressively pursues the goals of self-sufficiency and is attempting to drastically expand the production of some products. Most of the subsidies are directly bundled to production and represent a very trade distorting type of support. ${ }^{7}$ Only $13 \%$ can be classified as supporting activities for agriculture (infrastructure, education, etc.), representing a relatively small share in comparison with other countries (OECD 2017). Despite economic cycle fluctuations, total state support in absolute terms has been rather stable over the last two decades. Although its share in GDP has halved over a decade, it largely represents expansion of the GDP during the 2000s and support as a share of GDP is still considerably larger than in other industrialized countries.

Russian subsidies' allocation is based on a co-funding scheme between the federal and regional governments. Although Russian legislation stipulates that agricultural support is a primary responsibility of the regions, we observe a complicated negotiation process between the federal and regional levels. The regions have a large legal discretion in setting the sizes of different types of agricultural support. Each specific law regulating distribution of each type of subsidies defines certain boundaries set for each type of subsidies individually. They are generally rather broad and provide a substantial degree of discretion, leaving regional politicians with large decision-making powers. Local governments can also apply for federal co-funding if they choose to do so, with the federal government typically conditioning federal co-funding based on availability of regional programs of agricultural development that outline major regional agricultural priorities. Based on these programs, the regions sign a contract with the federal government on the co-funding of each type of subsidy. However, depending on the demand and availability of funds, the amount agreed to may need to be revised and corrected within the fiscal year via additional negotiations. Interestingly, the regions are expected to report on spending of the federal shares of the co-funding but not of the regional ones.

\footnotetext{
7 Distorting support is by definition likely to affect production incentives and, as a result, distort trade flows, undermining the idea of liberal markets (Potter and Burney 2002).
} 
Although Russian legislation provides clearer guidelines for federal co-funding than the regional one, the federal authorities still possess substantial discretionary powers in funding distribution. The allocation of the federal co-funding is guided by the State Program for Development of Agriculture 2013-2020, which determines major directions and priorities of the Russian agricultural sector. Each region's share of specific subsidies (e.g., livestock, crops, etc.) is regulated by laws that stipulate specific distribution formulas. In their essence, these formulas are similar to the principles of intergovernmental transfer distribution and would typically contain variables reflecting the amount of available federal funding, the degree of budgetary self-sufficiency, some measures of local agricultural production intensity (e.g., livestock index, crop area, etc.) and some coefficients that are set by the Ministry of Agriculture. The calculation of the latter appears to be rather non-transparent and may partially represent the ministry's discretionary leeway in subsidies allocation. On the other hand, the degree of the budgetary self-sufficiency is a ratio of an index measuring regional tax potential over an index of budgetary expenditures; ${ }^{8}$ it basically measures the extent a region can cover its budgetary needs with the locally generated tax resources. Despite these regulations, the de facto process of the negotiations on the size of federal co-funding lacks transparency and may be vulnerable to lobbying by interest groups (Frumina 2016). Even after the negotiations between regions and the federal government are over, the budget corrections may be as high as $30 \%$. Although replication of the distribution formulas has not been done due to unavailability of data, scholars typically find large unexplained imbalances in the size of federal co-funding (Uzun 2015; Shagaida et al. 2015). ${ }^{9}$

Regional lobbies utilize this autonomy despite the fact that Russia's institutional lobbying infrastructure may still be weak. Many enterprises use direct lobbying strategies including consultations with regional administrations, legislatures and the governor (Frye 2002; Guriev et al. 2010). Large agricultural enterprises, especially the ones operating within more than one region, may even be able to solicit federal authorities. In addition, numerous business associations have emerged facilitating exchange between enterprises and creating a link with the state authorities of various levels (Guriev et al. 2010). Some of the agricultural associations are very independent from the state, and some are highly integrated with regional and federal ministries. Uzun (Uzun 2017) argues that large agricultural enterprises managed to influence political decision making and to obtain disproportionately large levels of agricultural support.

General power relations between the levels of the government have changed dramatically over the past two decades in Russia, with regions enjoying large freedoms during the Yeltsin period in the 1990s. Each region bargained with Moscow over the authority, which resulted in large imbalances between regions (Zhuravskaya 2010; Ross 2010). During this period, local governments were characterized by an extreme elite capture (Guriev et al. 2010) and ad hoc intergovernmental transfers

\footnotetext{
${ }^{8}$ Both of the indices are calculated based on a methodology that involves multiple variables and replication is prohibited due to lack of data availability (Government of Russia 2004).

${ }^{9}$ Qualitative expert interviews conducted in Moscow and selected regions confirm this assertion.
}

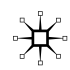


that generated large geographical fiscal imbalances (Zhuravskaya 2010). The commencement of Putin's regime in 2001 is normally associated with vast centralization processes within Russian intergovernmental relations (Robertson 2010; Reuter and Remington 2009). The regions were stripped of their already limited fiscal independence and were forced to transfer most of the tax revenues to the central authority with the hope of getting some parts back in the form of transfers. Elite capture of local governments and intergovernmental bargaining survived, but the power shifted to the federal level (Guriev et al. 2010; Zhuravskaya 2010; Parker and Thornton 2007). For instance, penetration of business interests in local legislatures can be illustrated by the fact that just under half of the regional legislature members owned businesses in the early 2010s (Reuter 2010). However, new rules of intergovernmental fiscal relationships improved substantially under Putin's regime (Jarocińska 2010). Nevertheless, we observe a growing bulk of evidence of the federal government's maximizing political support via manipulation of transfers (Jarocińska 2010; Marques et al. 2016), state lending (Schoors and Weill 2017) and tax arrears (Ponomareva and Zhuravskaya 2004).

Further important aspects of centralizing trends that occurred in 2010 were securing a dominant position of UR and the appointment of the governors by the center. During the period 2007-2015, UR was the leading political force in all of the regions we are considering in this study. Such a position was in part achieved by creating a vertical accountability system where "lower-standing" politicians had to reproduce successful election results for UR in order to stay in power (Konitzer-Smirnov 2005; Slider 2010; Reuter et al. 2016). Consequently, this shifted the accountability incentives from the local electorate to the governments of the higher tiers, as discussed in the section "Regional Allocation". Because of these incentives, regional politicians have to cater to local elites who may be instrumental in maximizing UR support. Despite the centralization trends, we observe a substantial variation in the degree of democratization and institutional development among the regions (Guriev and Vakulenko 2015). This, among other things, strongly depends on the governor. After 2005, all governors were appointed and evaluated by Putin instead of being elected. As a result, many newly appointed governors were not even from the region and would often commute to the region for work, while their families stayed in Moscow (Nye and Vasilyeva 2015). Governors had similar indirect electoral incentives as regional party leaders: their performance was evaluated based on their ability to improve UR's standing in the region, and in fact, often they would be party members themselves (Reuter and Robertson 2012).

\section{Data and Methods}

In order to test our hypotheses about the incentives of the federal and regional politicians in agricultural subsidies allocation, we utilize a data set encompassing 78 Russian regions and spanning from 2007 to $2015^{10}$ and distinguish between the regional

${ }_{10}$ Unfortunately, data for the 2011 year are not available for all regions. 
and federal shares of co-funding. The data were provided by the Russian Ministry of Agriculture with the assistance of the Nikonov All-Russian Institute of Agricultural Problems and Informatics based in Moscow. Data sources for our independent variables are from the Russian Federal State Statistical Agency, the Russian Central Election Commission, the database on Russian governors of the Institute for Industrial and Market Studies of the Higher School of Economics, and the "SPARK" database covering all registered enterprises.

\section{Variables}

As dependent variables, we use total regional and federal subsidies granted to farms in a region $i$ at a period $t$. This includes all the subsidies toward crop and livestock production, including direct payments, along with the subsidies toward the interest rates of short- and long-term credit. We exclude the support to general services as funds allocation is typically guided by separate development programs. The variables are deflated using OECD deflators for Russia and using 2010 as a base year. As we argued above, federal and regional politicians are likely to have substantial discretion over distribution of these funds.

Table 1 demonstrates the descriptive statistics of the independent variables utilized in the study. We follow Marques et al. (2016) and Govorun et al. (2016) and use the winning margin of UR against the closest runner-up party during the last elections as a proxy for political competition in a given region. In the Russian context, UR's landslide win typically means a strong grip over local elites and effective political machines (Reuter 2010; Reuter and Robertson 2012). ${ }^{11}$ Thus, we adopt a continuous operationalization of political competition. Larger winning margins imply lower political competition and the fact that a region hosts predominantly "core" voters. Conversely, close election results suggest higher numbers of "swing" voters and, thus, higher political competition. UR won in every single region throughout our sample with the exception of Altai Republic during the elections of 2003. ${ }^{12}$ The most serious competitor was the Communist Party (KPRF), who turned out to be the closest runner-up party in $70.83 \%$ of the cases within our sample. To test voter brokerage, we construct a Gini coefficient capturing the inequality in current assets among agricultural enterprises within a region. The idea is that a few large agricultural enterprises with few competitors in the regions should represent effective vote brokers for federal and regional politicians. Moreover, these enterprises should be in a better position to lobby for more subsidies on both levels of the government. The Gini coefficient is constructed on the whole universe of the enterprises available from the "Spark" database. Having gone through each observation, we see that those regions with higher Gini coefficients coincide with the ones we would predict

\footnotetext{
11 Whether political control of a given region is achieved via manipulation or is due to higher voters' support is not important for our hypotheses. We are essentially interested in how the Russian government responds to the regional political competition outcomes.

12 The "Agrarian Party" won a regional election by a margin of $4.31 \%$; we set the variable "winning margin" to zero to facilitate our estimations.
} 


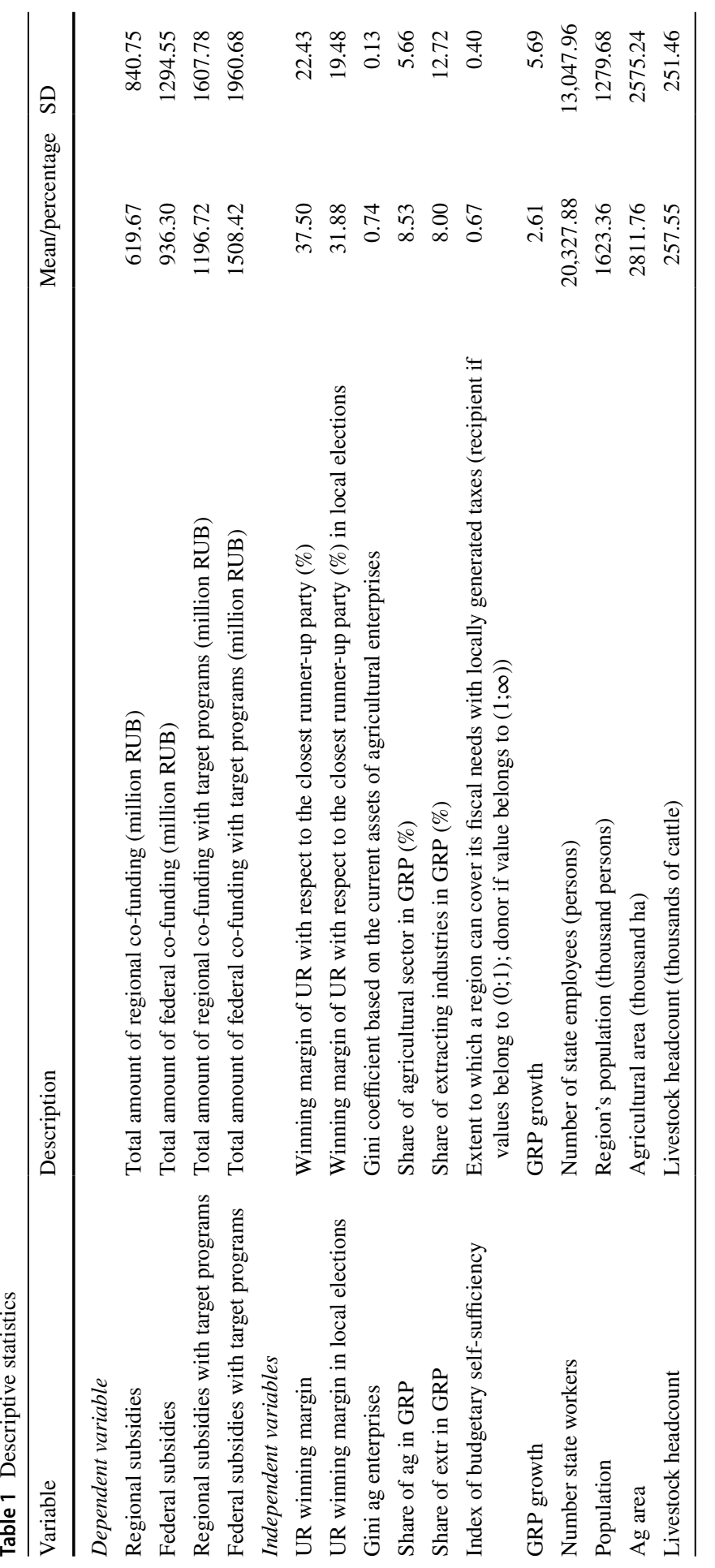


to host large farms and vice versa. ${ }^{13}$ As a result, we believe this is a good proxy for large farming within a region. We expect the regions with large farms to be more successful in obtaining agricultural subsidies and to facilitate the effects of the political competition.

We include a number of control variables. To reflect a region's general bureaucratic capacity, we include the number of state employees per regions. Furthermore, we control for the variables stipulated in a typical distribution formula. An important part of each formula is the index of budgetary self-sufficiency that is regularly published by the Ministry of Finance. If the federal government follows equalization objectives, we would expect this index to be negatively associated with the federal co-funding. However, we expect a positive sign for regional co-funding because fiscally strong regions should be able to afford more subsidies. Furthermore, depending on the type of subsidies, distribution formulas typically include some agricultural characteristics. The most basic ones are agricultural area and a livestock headcount, both of which are included in our models. The general importance of agriculture in the regional economy should be captured by the share of agriculture in the gross regional product (GRP). On the other hand, regions hosting oil and gas extraction industries should be in a better fiscal position to allocate regional subsidies for cofunding, which, in turn, may affect the federal government's decision to react to an above average fiscal capacity. Furthermore, we control for a region's population and GRP growth.

\section{Methods}

Agricultural subsidies are determined for each region based on the values of the previous years that are used as a baseline. Consequently, these variables are subject to autocorrelation. Since our panel data are of a dynamic nature and the unobserved panel-level effects are correlated with the lags of the dependent variable, we must include a lagged dependent variable among the regressors (Arellano and Bond 1991). To identify the model, we need to instrument this variable with instruments that are exogenous to the region-level fixed effects (Blundell and Bond 1998). To explore the link between the agricultural subsidies and the political economy variables, we estimate a two-step generalized method of moments (GMM) with finitesample corrected standard errors (Windmeijer 2005):

$$
Y_{i t}=\beta_{1} Y_{i t-1}+\beta_{2} X_{i t-1}+\beta_{3} S_{i t-1}+\beta_{4} Z_{i t-1}+\beta_{5} X_{i t-1} S_{i t-1}+\alpha_{i}+u_{i t}
$$

where $Y_{i t}$ is either total federal agricultural subsidies or regional co-funding in region $i$ at a period $t ; Y_{i t-1}$ is a lagged dependent variable; $X_{i t-1}$ represents a lagged winning margin of UR in a region $i ; S_{i t-1}$ is the Gini coefficient based on a farm's current assets within the region $i ; Z_{i t-1}$ is a vector of control variables; and, finally, $\alpha_{i}$ represents region- and year-specific fixed effects and $u_{i t}$ is an error term. We also include

\footnotetext{
13 We observe a substantial concentration of large farms in the European and South Siberian parts of Russia.
} 
an interaction term between UR's winning margin and the measure of farming scale inequality ("Gini ag enterprises"). We would expect the effect of the political competition to be moderated by the presence of large farms in a region. All the variables enter the estimation in logarithmic form, and the monetary variables are represented in real terms.

The system GMM estimation is based on the underlying assumption that lagged dependent variables are correlated with the unobserved panel-level effects. The methodology stipulates identification of the lagged dependent variable using instruments constructed from the first differences and levels of its own lags. In particular, this methodology constructs a matrix of instruments based on $Y_{i t-1-k}$ for the firstdifference equation and on $\Delta Y_{i t-1-k}$ for the equation in levels (Roodman 2009). Following Roodman's (2009) terminology, apart from the lagged dependent variables, we treat the following variables as "predetermined": agricultural area, livestock headcount and the share of agriculture in the GRP. Although unlikely, these variables could potentially be affected by the subsidies and, thus, we treat them as "predetermined." To address the "technical" endogeneity, we use the lags of the rest of the variables as "internal" instruments. To minimize the risk of autocorrelation and reduce the number of instruments, we use second-order lags throughout our specifications. In addition, the system GMM technique allows us to use classical "external" instruments. Finally, since Arellano and Bond (1991) and Blundell and Bond (1998) find the two-step standard errors to be downward biased (although more efficient), we implement a finite-sample correction, as suggested by Windmeijer (2005), to address this problem. ${ }^{14}$

We analyze two models for two different dependent variables, federal and regional agricultural subsidies, but with identical specifications. Although politics differ, the key determinants of spending decisions are all included on the right-hand side of the model and, thus, allow testing for different mechanisms of influence. For the former, political competition should motivate the federal government to distribute subsidies strategically, while for the latter it determines the extent of capture of the regional government.

Problems of endogeneity of the explanatory variables are inherent for this type of studies. In particular, the subsidies may affect the electoral success of UR within a region. In the end, this is what the incumbent party may intend to do: influence electoral outcomes with redistribution. We address this problem in two ways. First, we lag all the independent variables (including the winning margins of UR) because a vast majority of Russian budgetary decisions are made based on the previous year's information. We argue that agricultural subsidies in period $t$ cannot affect electoral outcomes in period $t-1$, which should minimize the danger for endogeneity. Second, we employ an instrumental variables (IV) approach to instrument for the winning margin of UR. The idea of the IV approach is that, in order to meet the exclusion restriction, the instrument is correlated with the instrumented variable but not with the independent variable (Wooldridge 2009). We follow Marques et al. (2016) and use vote share for the communist party in the previous election cycle as

$\overline{14}$ We utilize a user-written routine "xtabond2" in Stata software. 
an instrument. As the main opposition party, the vote share for this party during the previous elections should be correlated with the winning margin of UR but not with the levels of agricultural subsidies in the current period. As a result, the IV meets the exclusion restriction.

\section{Results}

Before proceeding to the estimation results, let us take a look at how subsidies evolved over the period of our panel data. Figure 1 demonstrates the dynamics. The first observation is that federal co-funding increased in absolute terms, whereas regional levels have largely stayed the same. After 2013, both amounts went down in line with the reductions in GDP growth during that time. Despite this, the federal share stayed way above the regional funding. This may be due to centralization of fiscal intergovernmental relations over the last decade and a half. For instance, according to RosStat's official yearbooks, the number of regions that are fiscally self-sufficient ${ }^{15}$ went down from 24 in 2005 to 14 in 2015. These net-contributing regions are represented either by Moscow and St. Petersburg or by oil- and gas-producing regions like Tatarstan Republic or Tyumen. As a consequence of the centralizing reforms, regional budgets started relying more on transfers from the federal level and agricultural subsidies were not an exception. Reliance on federal transfers may have ensured the central government's ability to control the region via redistributive politics.

The data also show that the incumbent party in Russia managed to cement its dominance to different degrees across the regions. Figure 2 presents the distribution of votes for UR during the two elections in our sample: 2007 and 2011. We observe that, during both elections, there is a substantial variation in the support. For instance, during the 2007 elections, UR enjoyed the lowest support in one of the most industrialized regions, Yaroslavskaya oblast $(53.13 \%)$, while the highest support (over 90\%) was typically achieved in the oil-producing republics and the North Caucasus (Panov and Ross 2013). One should treat these figures with caution since these regions are typically described as the most authoritarian with weak democratic institutions (Holland 2016). These regions are often closely controlled by the federal government, and local elites are incentivized to choke any type of political opposition.

Average support of UR decreased from 2007 to 2011, from 65.3\% (315 seats in the parliament) to $49.3 \%$ (238 seats). We observe a similar picture with the UR's winning margin: it dropped from an average of 53.3\% during 2007 election to $29.0 \%$ during 2011 elections. If UR was overconfident in 2007 with the lowest winning margin of $37.8 \%$ in Altai Krai, in 2011 there were 12 regions with the winning margin below $10 \%$. The popularity dropped in light of the 2008 financial crisis that severely hit Russia and Putin's government was struggling to secure even these

15 The tax base is sufficient to generate the necessary budgetary resources to cover regional expenses.

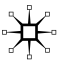




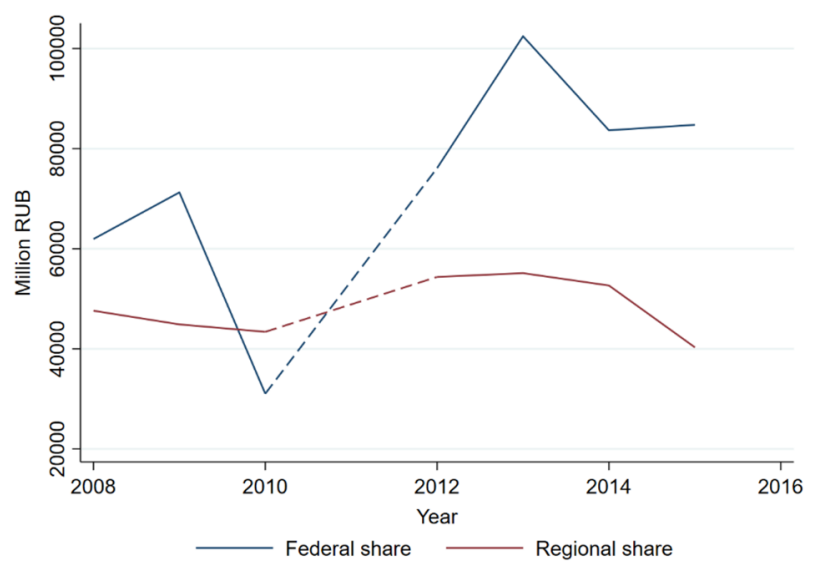

Fig. 1 Federal and regional shares of agricultural subsidies in 2010 million RUB (note that the dashed line indicates missing observations for 2011). Source: Russian Ministry of Agriculture (2015)

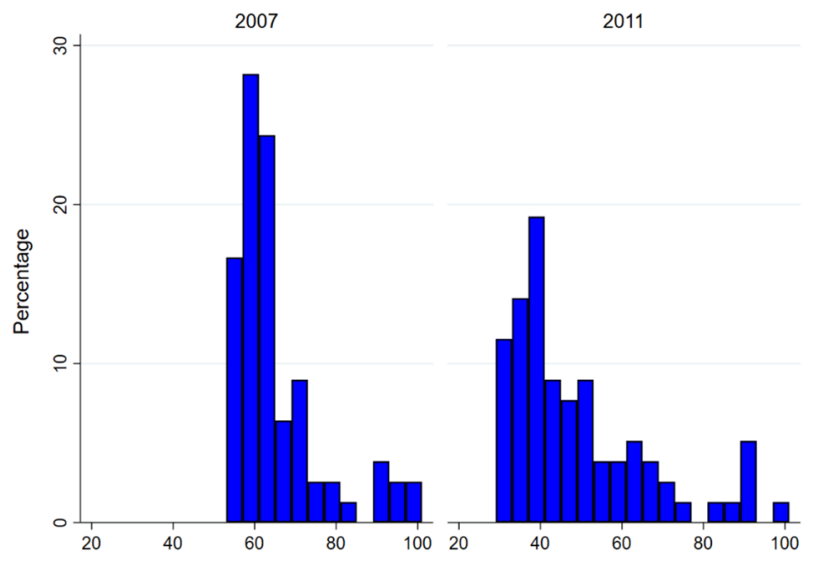

Fig. 2 Distribution of votes for the incumbent party in 2007 and 2011 elections within the sample. Source: Authors' calculations

modest (by Russian standards) results (Enikolopov et al. 2013). However, the variation in the support still persisted along with Moscow's strong grip over the oil-producing regions and Northern Caucasus republics.

We also see signs of industry concentration within the period of our sample. Thus, the average Gini coefficient based on the farms' current assets went from 0.67 in 2007 to 0.85 in 2015 . These trends are in line with the emergence of mega-farms in Russia (Visser et al. 2012; Uzun and Lerman 2017). Many of these enterprises are ran by oligarchs who control roughly one quarter of the farmland in the most fertile regions (Visser et al. 2012).

Our main estimations are presented in Table 2. In particular, we first present a baseline a system GMM dynamic panel model as a baseline specification. Then we 


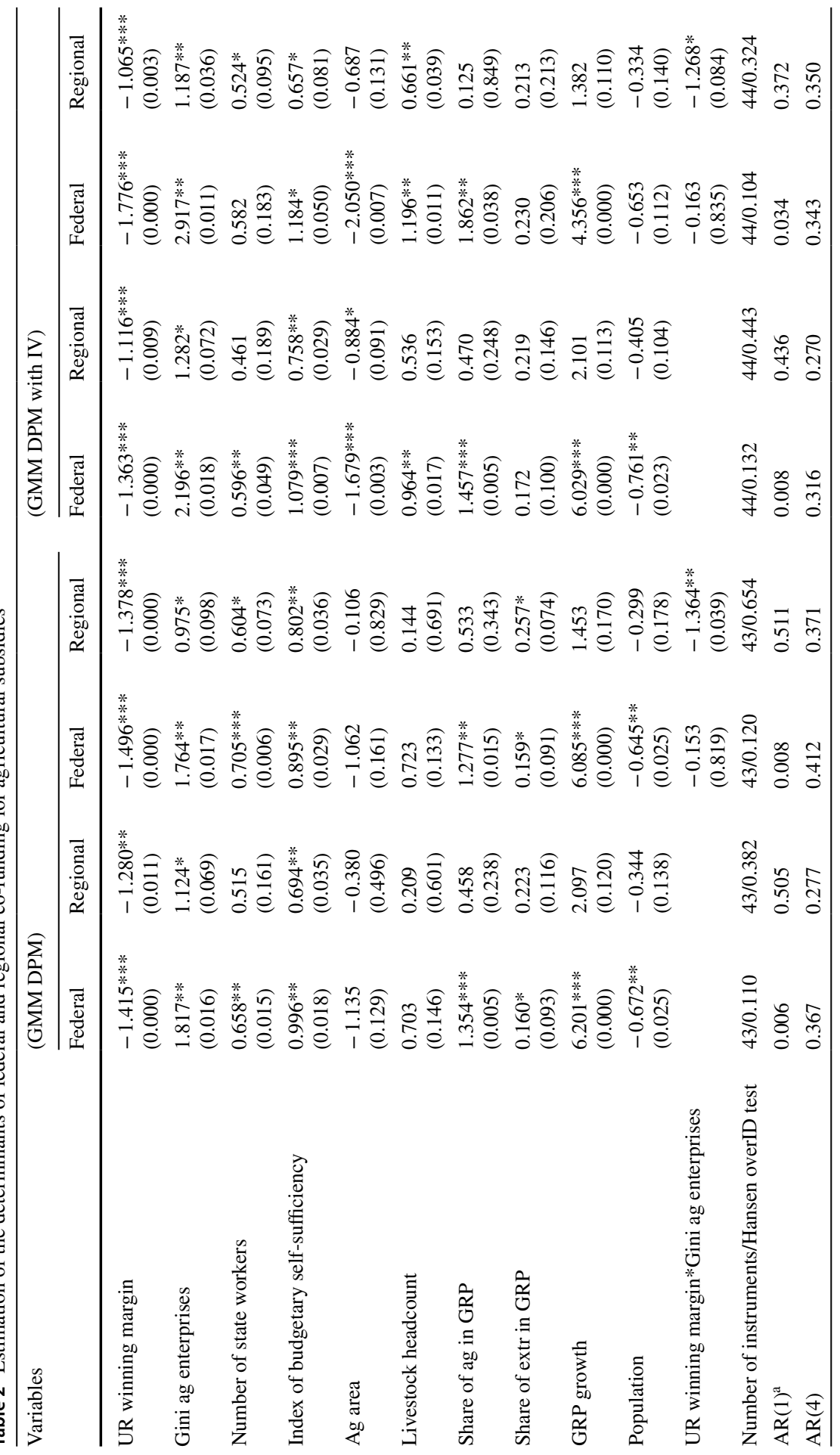

售。 


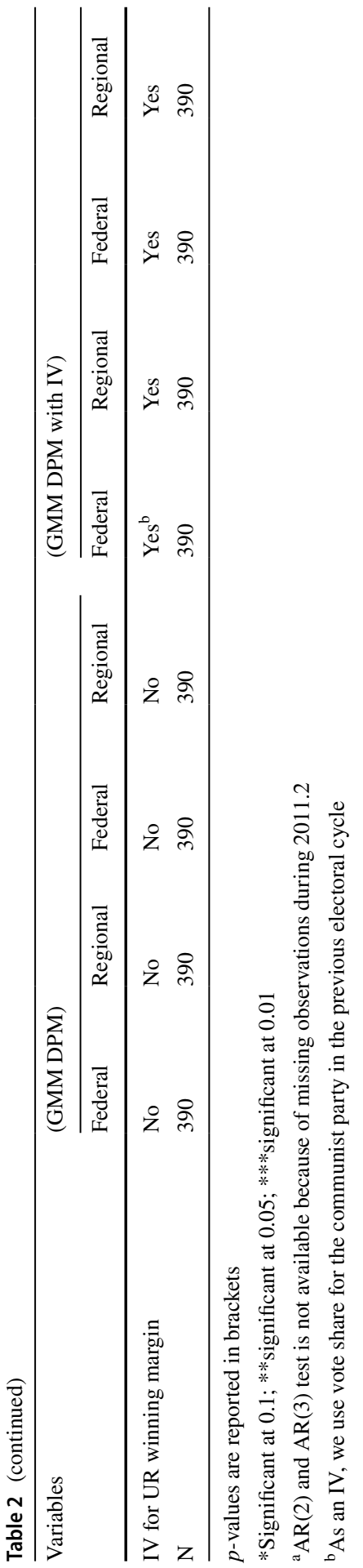


add our instrument for UR's winning margin and the interaction terms between the UR's winning margin and the Gini coefficient of the farms' current assets. Examining the control variables first, we see that the coefficient of the budgetary self-sufficiency is also positive in the specification with the federal co-funding as a dependent variable, suggesting the federal government allocates more co-funding to the fiscally strong regions. This suggests that intergovernmental equalization objectives are not implemented in the context of agricultural subsidies. The application-based nature of the federal co-funding probably results in richer regions having more ambitious agricultural programs and, as a result, applying for more subsidies. In addition, we find some evidence that regions with higher bureaucratic capacity - a higher number of state employees - appear to be more successful in obtaining federal subsidies. Also faster growing regions tend to be more successful with the federal co-funding.

Turning to our main hypotheses, the first observation is that, across our specifications, UR's winning margin is negatively and significantly associated with both regional and federal agricultural subsidies. This finding is in line with the "swing" voter hypothesis since federal transfers appear to be directed to the regions where the incumbent party faces more competition. At the regional level, local politicians appear to have a similar strategy: they allocate more agricultural subsidies if UR faces fiercer competition. The effects appear to be relatively large in comparison with the other covariates.

We also find a consistent effect of our proxy for large agricultural business concentration. In particular, the coefficient of the Gini index based on the farms' current assets is positive and significant across the specifications. This means that the regions hosting large farms are more likely to obtain both regional and federal co-funding of agricultural subsidies. Importantly, specifications with regional cofunding as a dependent variable demonstrate negative and significant coefficients of the interactions between the Gini coefficient and UR's winning margin. Thus, the effect of large-scale farming within the region is amplified by UR's small winning margins. To illustrate these findings graphically, we plot the marginal effects of the farming mode on the predicted values of regional and federal subsidies depending on the UR's winning margin (Fig. 3). For the sake of simplicity, we set the winning margin at the value of the top decile of its distribution to illustrate the "core" region and at the bottom decile for the "swing" region. As a result, we can observe two distinct effects of the Gini coefficient (together with $95 \%$ confidence intervals) with low and high UR's winning margins. Consistent with our theory, we see that the regions where large farms dominate local agriculture are likely to obtain more of both regional and federal co-funding of agricultural subsidies. Moreover, this effect appears to be facilitated by high political competition (low UR's winning margins) on the regional level. At the federal level, the effect seems to be additive (shift of the curve upwards) and multiplicative at the regional level (the slope becomes steeper). In sum, the evidence is in line with our hypothesis that federal and regional governments use large agricultural businesses as vote brokers. 

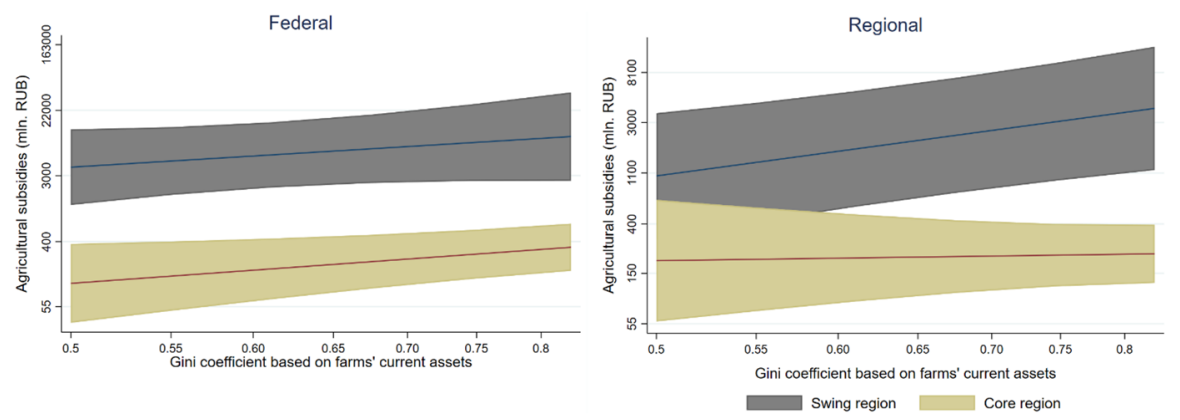

Fig. 3 Predicted agricultural subsidies for "swing" and "core" regions depending on the farming mode. Source: Authors' calculations

\section{Robustness Check}

We first check whether our results hold using more parsimonious models. In particular, we re-estimate the same specifications using simple fixed-effects models without inclusion of the lagged dependent variable on the right-hand side (see Appendix 1 for details). The results largely mirror the ones presented in Table 2. Second, because we used total agricultural transfers as a dependent variable, it may be informative to check whether the established relationships hold with specific types of subsidies as dependent variables. Allocation and distribution of each category of agricultural subsidies are guided by separate governmental decrees. To see whether our results hold for specific subsidies, we estimate specifications with three different dependent variables: crops, livestock and credit. Table 3 presents the estimation results. We see that the effect of UR's winning margin is preserved throughout the specifications. The same holds for most of the coefficients of the proxy for largescale farming (only one coefficient is insignificant for the specification with regional livestock subsidies as a dependent variable). However, the interaction terms between the Gini coefficients and UR's winning margin are negative and significant only in the specifications with livestock subsidies as dependent variables. Livestock farming is typically more labor intensive and, thus, may represent better voter mobilization possibilities.

Another important robustness check is based on a more aggregate measure of agricultural subsidies and includes target federal programs and other subsidies that are not accounted for by the main categories. One of these programs, for instance, is called "Social Development of Rural Areas until 2020." Other programs target specific regions (e.g., "Socio-Economic Development of the Republic of Ingushetia for 2010-2016") and could potentially represent redistributive measures of the federal government. Finally, it is not clear what the category "other subsidies" (as classified by the Russian Ministry of Agriculture) refers to. Unfortunately, we do not have more detailed data for these subcategories. However, regressing this aggregate measure of agricultural support on the same set of explanatory variables generates results similar to our main estimations (see Appendix 2 for details). One exception is the coefficient of the Gini index based on current assets of agricultural enterprises, 


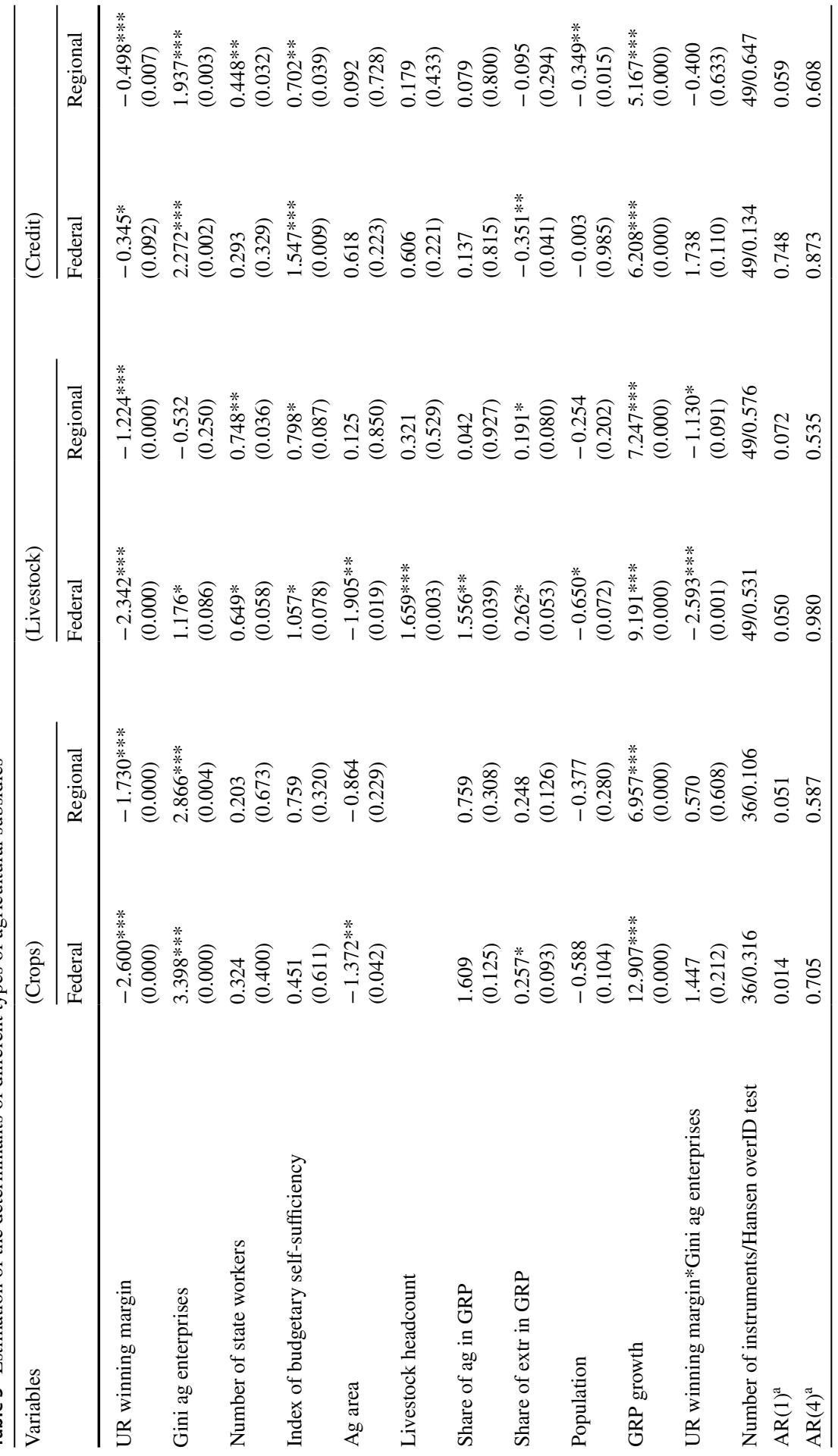

桀 


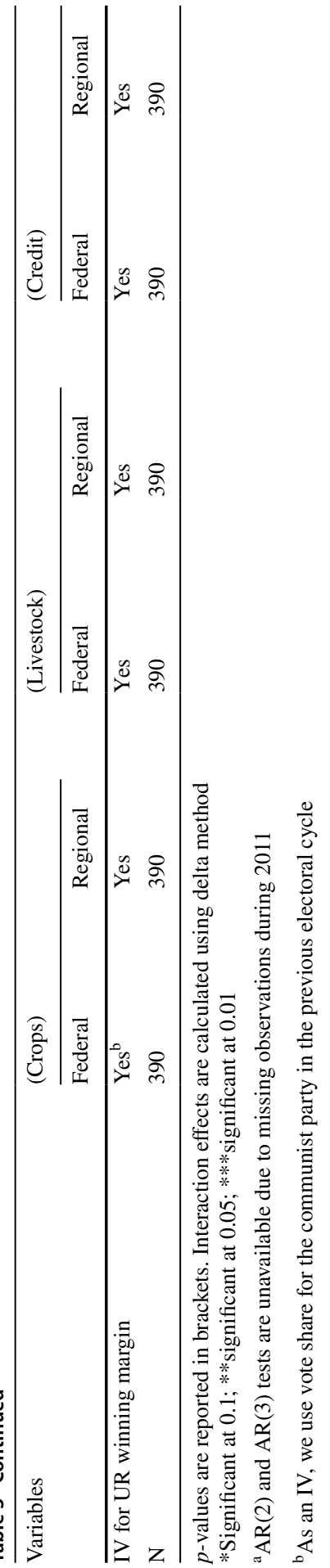


which we cannot claim to be different from zero. The reason for this may be the fact that total agricultural support includes federal target programs and other funding oriented toward public goods financing, which is not distributed among agricultural producers. As a result, the effect of large farms gets obscured by this noise.

We further experiment with the proxies for UR's regional dominance. First, we utilize the conjecture that UR may be interested in ensuring its dominance not only within the Duma elections, but also within the elections of regional parliamentarians. A solid dominance in the regional legislatures may increase the likelihood of winning the federal-level elections. As a result, both regional and federal politicians may have incentives to redistribute in order to maximize political support in the regional legislatures. Consequently, we should observe similar relationships with respect to the elections of regional parliamentarians. To test this hypothesis, we substitute UR's winning margin in the Duma election with the winning margin of its regional representation. Similar to our main estimations, we use a vote share of the communist party in the last elections as an instrument. The coefficients of our variables of interest and the interaction term are very similar to our main estimations (see Appendix 2 for details). Finally, we re-estimate the regressions, substituting the UR's winning margin with a simple vote share. Estimation results are very similar to Table 2 (see Appendix 3 for details). However, the interaction terms for the regional subsidies are not significant anymore (although of the expected sign).

\section{Conclusion}

This study contributes to the literature on the political economy of redistribution policies by examining Russian politicians' incentives to cater to an important group of voters: agricultural producers and rural residents. We modeled politicians' behavior in the context of agricultural subsidies distribution, both at federal and regional levels, and found that one of the major factors guiding the distribution of agricultural subsidies is the success of the dominant party (United Russia) within Russia's authoritarian regime. Moreover, we sought to answer the question of how the politicians direct agricultural subsidies, and found evidence that the regional politicians may use large agricultural enterprises as vote brokers.

Examining the incentives of the central government, we contribute to the debate about whether it targets the "core" or "swing" voters while redistributing resources. In the context of agricultural subsidies distribution, we find support for the "swing" voters hypothesis because the federal government appears to allocate larger cofunding shares of agricultural subsidies to those regions where the incumbent party faces more competition. In other words, the federal government appears to buy votes in those regions where it feels their investments will bring higher marginal returns. This study goes beyond similar studies of Jarocińska (2010), Marques et al. (2016) or Popov (2004), who look at the allocation of intergovernmental transfers. Instead, we focus on a very specific redistribution problem: agricultural subsidies toward a very concrete interest group: agricultural producers. Rural voters may be of central importance for UR because its ability to cement regional support has been largely based on mobilizing rural residents with the help of strong local leaders (Golosov 
2014). Transfers may simply generate higher marginal utility for poorer rural voters and, thus, represent an attractive target group for the politicians (Magaloni 2008).

Although fiscal centralization has increased under Russia's authoritarian regime, we find regional governments to be rather free in redistribution decisions and to be largely driven by considerations of the political economy. Despite the authoritarian context and consequently weak accountability mechanisms between local voters and politicians, the hierarchical organization of the incumbent party incentivizes regional politicians to maximize political support. In doing so, political parties may rationally solicit more narrow interest groups when political competition intensifies (Cox 1990). On the other hand, local interest groups may face higher risks seeking rents from a particular party knowing that there is strong political competition in the region (Bardhan and Mookherjee 2000). Our estimations grant support to the Cox's (1990) hypothesis because larger amounts of regional co-funding of agricultural subsidies are associated with higher political competition. UR may need to cater to different special interest groups should it feel that these "investments in vote buying" could improve their political support in the next elections.

We find that local agricultural elites are an important stakeholder in local redistributive politics. In particular, regions with highly unequal distribution of farm size appear to be more successful in obtaining larger federal and regional amounts of agricultural subsidies. This may reflect both superior lobbying capacity of the super-large farms that may control hundreds of thousands of ha and the government's preference to deal with larger agricultural producers. Importantly, regional governments appear to instrumentalize agricultural subsidies and use large agricultural enterprises as vote brokers, conditioning subsidies on mobilization of voter groups that could be influenced by a particular enterprise. These findings are in line with Frye et al. (2018), who demonstrates that the most prevalent way of voter mobilization in Russia is intimidation at their workplace.

Acknowledgements Open access funding provided by Projekt DEAL. We thank anonymous referees for constructive comments.

Open Access This article is licensed under a Creative Commons Attribution 4.0 International License, which permits use, sharing, adaptation, distribution and reproduction in any medium or format, as long as you give appropriate credit to the original author(s) and the source, provide a link to the Creative Commons licence, and indicate if changes were made. The images or other third party material in this article are included in the article's Creative Commons licence, unless indicated otherwise in a credit line to the material. If material is not included in the article's Creative Commons licence and your intended use is not permitted by statutory regulation or exceeds the permitted use, you will need to obtain permission directly from the copyright holder. To view a copy of this licence, visit http://creativecommons.org/ licenses/by/4.0/. 


\section{Appendix 1: Fixed-Effects Estimations}

\begin{tabular}{|c|c|c|c|c|}
\hline \multirow{2}{*}{$\frac{\text { Variables }}{\text { UR winning margin }}$} & \multicolumn{2}{|c|}{ Total federal subsidies } & \multicolumn{2}{|c|}{ Total regional subsidies } \\
\hline & $\begin{array}{l}-0.372 * * \\
(0.011)\end{array}$ & $\begin{array}{l}-1.002 * * * \\
(0.000)\end{array}$ & $\begin{array}{l}-0.338^{* *} \\
(0.024)\end{array}$ & $\begin{array}{l}-0.814 \text { *** } \\
(0.000)\end{array}$ \\
\hline Gini ag enterprises & $\begin{array}{l}2.661 * * * \\
(0.002)\end{array}$ & $\begin{array}{l}9.113 * * * \\
(0.000)\end{array}$ & $\begin{array}{l}3.241 * * * \\
(0.001)\end{array}$ & $\begin{array}{l}8.115^{* * *} \\
(0.000)\end{array}$ \\
\hline Number of state workers & $\begin{array}{l}0.327 \\
(0.184)\end{array}$ & $\begin{array}{l}0.178 \\
(0.391)\end{array}$ & $\begin{array}{l}0.729 * * * \\
(0.005)\end{array}$ & $\begin{array}{l}0.616^{* * * *} \\
(0.007)\end{array}$ \\
\hline Index of budgetary self-sufficiency & $\begin{array}{l}0.192 \\
(0.630)\end{array}$ & $\begin{array}{l}0.262 \\
(0.525)\end{array}$ & $\begin{array}{l}0.253 \\
(0.568)\end{array}$ & $\begin{array}{l}0.306 \\
(0.511)\end{array}$ \\
\hline $\mathrm{Ag}$ area & $\begin{array}{l}1.415 \\
(0.411)\end{array}$ & $\begin{array}{l}1.432 \\
(0.319)\end{array}$ & $\begin{array}{l}1.975 \\
(0.226)\end{array}$ & $\begin{array}{l}1.989 \\
(0.167)\end{array}$ \\
\hline Livestock headcount & $\begin{array}{l}-1.296^{*} \\
(0.070)\end{array}$ & $\begin{array}{l}-1.013 \\
(0.145)\end{array}$ & $\begin{array}{l}-1.702 * * \\
(0.046)\end{array}$ & $\begin{array}{l}-1.487^{*} \\
(0.078)\end{array}$ \\
\hline Share of ag in GRP & $\begin{array}{l}-0.638^{* *} \\
(0.032)\end{array}$ & $\begin{array}{l}-0.541^{*} \\
(0.063)\end{array}$ & $\begin{array}{l}-0.741^{* *} \\
(0.023)\end{array}$ & $\begin{array}{l}-0.668^{* *} \\
(0.037)\end{array}$ \\
\hline Share of extr in GRP & $\begin{array}{l}0.212 \\
(0.192)\end{array}$ & $\begin{array}{l}0.132 \\
(0.385)\end{array}$ & $\begin{array}{l}0.063 \\
(0.694)\end{array}$ & $\begin{array}{l}0.002 \\
(0.990)\end{array}$ \\
\hline GRP growth & $\begin{array}{l}-1.314 \\
(0.167)\end{array}$ & $\begin{array}{l}-1.173 \\
(0.179)\end{array}$ & $\begin{array}{l}0.166 \\
(0.855)\end{array}$ & $\begin{array}{l}0.273 \\
(0.739)\end{array}$ \\
\hline Population & $\begin{array}{l}-0.306^{* *} \\
(0.043)\end{array}$ & $\begin{array}{l}-0.246^{* *} \\
(0.050)\end{array}$ & $\begin{array}{l}-0.508^{* * * *} \\
(0.003)\end{array}$ & $\begin{array}{l}-0.462^{* * *} \\
(0.002)\end{array}$ \\
\hline UR winning margin*Gini ag enterprises & & $\begin{array}{l}-1.851^{* * *} \\
(0.000)\end{array}$ & & $\begin{array}{l}-1.398^{* * * *} \\
(0.002)\end{array}$ \\
\hline Constant & $\begin{array}{l}10.558 \\
(0.460)\end{array}$ & $\begin{array}{l}11.409 \\
(0.351)\end{array}$ & $\begin{array}{l}-0.071 \\
(0.996)\end{array}$ & $\begin{array}{l}0.572 \\
(0.961)\end{array}$ \\
\hline Within $\mathrm{R}^{2}$ & 0.356 & 0.403 & 0.431 & 0.455 \\
\hline $\mathrm{N}$ & 467 & 467 & 467 & 467 \\
\hline
\end{tabular}

$p$-values are reported in brackets

Note: no lagged dependent variables were included among the independent variables. All independent variables are lagged

*Significant at $0.1 ; * *$ significant at $0.05 ; * * *$ significant at 0.01

\section{Appendix 2: Estimations for the Robustness Check}

\begin{tabular}{lllll}
\hline Variables & \multicolumn{2}{l}{ GMM DPM with IV } & \\
\cline { 2 - 4 } & $\begin{array}{l}\text { Total federal sup- } \\
\text { port with target } \\
\text { programs }\end{array}$ & $\begin{array}{l}\text { Total regional } \\
\text { support with target } \\
\text { programs }\end{array}$ & $\begin{array}{l}\text { Total federal } \\
\text { subsidies }\end{array}$ & $\begin{array}{l}\text { Total regional } \\
\text { subsidies }\end{array}$ \\
\hline $\begin{array}{l}\text { UR winning } \\
\text { margin }\end{array}$ & $\begin{array}{l}-1201.154^{* * *} \\
(0.006)\end{array}$ & $\begin{array}{l}-264.045^{*} \\
(0.094)\end{array}$ & \\
\hline
\end{tabular}




\section{Appendix 2: (continued)}

\begin{tabular}{|c|c|c|c|c|}
\hline \multirow[t]{2}{*}{ Variables } & \multicolumn{4}{|l|}{ GMM DPM with IV } \\
\hline & $\begin{array}{l}\text { Total federal sup- } \\
\text { port with target } \\
\text { programs }\end{array}$ & $\begin{array}{l}\text { Total regional } \\
\text { support with target } \\
\text { programs }\end{array}$ & $\begin{array}{l}\text { Total federal } \\
\text { subsidies }\end{array}$ & $\begin{array}{l}\text { Total regional } \\
\text { subsidies }\end{array}$ \\
\hline $\begin{array}{l}\text { Local UR winning } \\
\text { margin }\end{array}$ & & & $\begin{array}{l}-0.457 * * * \\
(0.000)\end{array}$ & $\begin{array}{l}-0.589 * * * \\
(0.000)\end{array}$ \\
\hline Gini ag enterprises & $\begin{array}{l}216.709 \\
(0.743)\end{array}$ & $\begin{array}{l}-314.634 \\
(0.264)\end{array}$ & $\begin{array}{l}1.238 * * * \\
(0.000)\end{array}$ & $\begin{array}{l}1.455^{* * * *} \\
(0.000)\end{array}$ \\
\hline $\begin{array}{l}\text { Number of state } \\
\text { workers }\end{array}$ & $\begin{array}{l}125.824 \\
(0.716)\end{array}$ & $\begin{array}{l}-60.036 \\
(0.682)\end{array}$ & $\begin{array}{l}0.509 * * * \\
(0.000)\end{array}$ & $\begin{array}{l}0.552 * * * \\
(0.000)\end{array}$ \\
\hline $\begin{array}{l}\text { Index of budgetary } \\
\text { self-sufficiency }\end{array}$ & $\begin{array}{l}1445.299 \\
(0.118)\end{array}$ & $\begin{array}{l}254.353 \\
(0.329)\end{array}$ & $\begin{array}{l}1.169 * * * \\
(0.000)\end{array}$ & $\begin{array}{l}0.962 * * * \\
(0.000)\end{array}$ \\
\hline $\mathrm{Ag}$ area & $\begin{array}{l}-1912.251 * \\
(0.066)\end{array}$ & $\begin{array}{l}-368.936 \\
(0.189)\end{array}$ & $\begin{array}{l}-0.545^{* * * *} \\
(0.009)\end{array}$ & $\begin{array}{l}-0.846^{* * * *} \\
(0.000)\end{array}$ \\
\hline $\begin{array}{l}\text { Livestock head- } \\
\text { count }\end{array}$ & $\begin{array}{l}1200.296 \\
(0.128)\end{array}$ & $\begin{array}{l}548.097 * * \\
(0.021)\end{array}$ & $\begin{array}{l}0.184 \\
(0.223)\end{array}$ & $\begin{array}{l}0.504 * * * \\
(0.010)\end{array}$ \\
\hline $\begin{array}{l}\text { Share of ag in } \\
\text { GRP }\end{array}$ & $\begin{array}{l}2197.787 * * \\
(0.026)\end{array}$ & $\begin{array}{l}-318.684 \\
(0.260)\end{array}$ & $\begin{array}{l}0.841 * * * \\
(0.004)\end{array}$ & $\begin{array}{l}0.858 * * * \\
(0.001)\end{array}$ \\
\hline $\begin{array}{l}\text { Share of extr in } \\
\text { GRP }\end{array}$ & $\begin{array}{l}294.130 * \\
(0.069)\end{array}$ & $\begin{array}{l}65.383 \\
(0.322)\end{array}$ & $\begin{array}{l}0.263^{* * * *} \\
(0.000)\end{array}$ & $\begin{array}{l}0.073 \\
(0.136)\end{array}$ \\
\hline GRP growth & $\begin{array}{l}7005.954 * * * \\
(0.000)\end{array}$ & $\begin{array}{l}1430.680 * \\
(0.064)\end{array}$ & $\begin{array}{l}2.484 * * * \\
(0.000)\end{array}$ & $\begin{array}{l}6.619 * * * \\
(0.000)\end{array}$ \\
\hline Population & $\begin{array}{l}-643.730 \\
(0.150)\end{array}$ & $\begin{array}{l}23.052 \\
(0.851)\end{array}$ & $\begin{array}{l}-0.420 * * * \\
(0.000)\end{array}$ & $\begin{array}{l}-0.629 * * * \\
(0.000)\end{array}$ \\
\hline $\begin{array}{l}\text { UR winning } \\
\text { margin*Gini ag } \\
\text { enterprises }\end{array}$ & $\begin{array}{l}176.954 \\
(0.858)\end{array}$ & $\begin{array}{l}353.111 \\
(0.414)\end{array}$ & $\begin{array}{l}-1.147 \\
(0.386)\end{array}$ & $\begin{array}{l}-1.840 * * * \\
(0.000)\end{array}$ \\
\hline $\begin{array}{l}\text { Number of instru- } \\
\text { ments/Hansen } \\
\text { overID test }\end{array}$ & $46 / 0.397$ & $46 / 0.248$ & $47 / 0.516$ & $47 / 0.268$ \\
\hline $\operatorname{AR}(1)^{1}$ & 0.035 & 0.282 & 0.048 & 0.027 \\
\hline $\operatorname{AR}(4)^{1}$ & 0.370 & 0.606 & 0.337 & 0.942 \\
\hline$N$ & 390 & 390 & 385 & 385 \\
\hline
\end{tabular}

$p$-values are reported in brackets. Interaction effects are calculated using delta method *Significant at 0.1 ; **significant at 0.05 ; ***significant at 0.01

${ }^{1} \mathrm{AR}(2)$ and $\mathrm{AR}(3)$ tests are unavailable due to missing observations during 2011. All specifications use vote share for the communist party in the previous electoral cycle as an IV 
Appendix 3: Estimations with a Simple Vote Share as a Measure of Political Competition

\begin{tabular}{|c|c|c|c|c|c|c|c|c|}
\hline \multirow[t]{2}{*}{ Variables } & \multicolumn{4}{|c|}{ (GMM DPM) } & \multicolumn{4}{|c|}{ (GMM DPM with IV) } \\
\hline & Federal & Regional & Federal & Regional & Federal & Regional & Federal & Regional \\
\hline $\begin{array}{l}\text { Vote share } \\
\text { for the } \\
\text { UR }\end{array}$ & $\begin{array}{l}-3.460 * * * \\
(0.000)\end{array}$ & $\begin{array}{l}-2.706^{* *} \\
(0.040)\end{array}$ & $\begin{array}{l}-3.482 * * * \\
(0.000)\end{array}$ & $\begin{array}{l}-2.942 * * * \\
(0.007)\end{array}$ & $\begin{array}{l}-3.383^{* * *} \\
(0.000)\end{array}$ & $\begin{array}{l}-2.522 * * \\
(0.025)\end{array}$ & $\begin{array}{l}-4.343^{* * *} \\
(0.000)\end{array}$ & $\begin{array}{l}-2.455^{* * *} \\
(0.017)\end{array}$ \\
\hline $\begin{array}{r}\text { Gini ag } \\
\text { enter- } \\
\text { prises }\end{array}$ & $\begin{array}{l}1.519 * \\
(0.066)\end{array}$ & $\begin{array}{l}1.171^{*} \\
(0.067)\end{array}$ & $\begin{array}{l}1.508 * * \\
(0.027)\end{array}$ & $\begin{array}{l}0.938 \\
(0.168)\end{array}$ & $\begin{array}{l}1.935 * * \\
(0.044)\end{array}$ & $\begin{array}{l}1.235^{*} \\
(0.076)\end{array}$ & $\begin{array}{l}2.596 * * \\
(0.036)\end{array}$ & $\begin{array}{l}0.966 \\
(0.164)\end{array}$ \\
\hline $\begin{array}{c}\text { Number } \\
\text { of state } \\
\text { workers }\end{array}$ & $\begin{array}{l}0.540 * \\
(0.067)\end{array}$ & $\begin{array}{l}0.335 \\
(0.309)\end{array}$ & $\begin{array}{l}0.622 * * \\
(0.040)\end{array}$ & $\begin{array}{l}0.388 \\
(0.242)\end{array}$ & $\begin{array}{l}0.487 \\
(0.136)\end{array}$ & $\begin{array}{l}0.332 \\
(0.309)\end{array}$ & $\begin{array}{l}0.484 \\
(0.333)\end{array}$ & $\begin{array}{l}0.359 \\
(0.259)\end{array}$ \\
\hline $\begin{array}{l}\text { Index of } \\
\text { budget- } \\
\text { ary } \\
\text { self-suf- } \\
\text { ficiency }\end{array}$ & $\begin{array}{l}0.902^{*} \\
(0.059)\end{array}$ & $\begin{array}{l}0.690 * * \\
(0.019)\end{array}$ & $\begin{array}{l}0.800 \\
(0.111)\end{array}$ & $\begin{array}{l}0.744^{* * *} \\
(0.025)\end{array}$ & $\begin{array}{l}0.990 * * \\
(0.034)\end{array}$ & $\begin{array}{l}0.683^{* *} \\
(0.018)\end{array}$ & $\begin{array}{l}1.196^{* * *} \\
(0.047)\end{array}$ & $\begin{array}{l}0.584 \\
(0.185)\end{array}$ \\
\hline $\mathrm{Ag}$ area & $\begin{array}{l}-1.334 \\
(0.142)\end{array}$ & $\begin{array}{l}-0.792 \\
(0.197)\end{array}$ & $\begin{array}{l}-1.358 \\
(0.147)\end{array}$ & $\begin{array}{l}-0.587 \\
(0.367)\end{array}$ & $\begin{array}{l}-1.989 * * * \\
(0.007)\end{array}$ & $\begin{array}{l}-1.042 * \\
(0.089)\end{array}$ & $\begin{array}{l}-2.547^{* * *} * \\
(0.003)\end{array}$ & $\begin{array}{l}-0.778 \\
(0.222)\end{array}$ \\
\hline $\begin{array}{c}\text { Livestock } \\
\text { head- } \\
\text { count }\end{array}$ & $\begin{array}{l}0.791 \\
(0.161)\end{array}$ & $\begin{array}{l}0.389 \\
(0.344)\end{array}$ & $\begin{array}{l}0.815 \\
(0.162)\end{array}$ & $\begin{array}{l}0.357 \\
(0.403)\end{array}$ & $\begin{array}{l}1.108 * * \\
(0.028)\end{array}$ & $\begin{array}{l}0.555 \\
(0.150)\end{array}$ & $\begin{array}{l}1.405^{* * *} \\
(0.005)\end{array}$ & $\begin{array}{l}0.598 \\
(0.112)\end{array}$ \\
\hline $\begin{array}{c}\text { Share of } \\
\text { ag in } \\
\text { GRP }\end{array}$ & $\begin{array}{l}1.395 * * \\
(0.014)\end{array}$ & $\begin{array}{l}0.626 \\
(0.196)\end{array}$ & $\begin{array}{l}1.327 * * \\
(0.031)\end{array}$ & $\begin{array}{l}0.664 \\
(0.254)\end{array}$ & $\begin{array}{l}1.517 * * \\
(0.017)\end{array}$ & $\begin{array}{l}0.575 \\
(0.215)\end{array}$ & $\begin{array}{l}2.015^{* * *} \\
(0.042)\end{array}$ & $\begin{array}{l}0.198 \\
(0.823)\end{array}$ \\
\hline $\begin{array}{c}\text { Share of } \\
\text { extr in } \\
\text { GRP }\end{array}$ & $\begin{array}{l}0.127 \\
(0.227)\end{array}$ & $\begin{array}{l}0.199 \\
(0.171)\end{array}$ & $\begin{array}{l}0.122 \\
(0.255)\end{array}$ & $\begin{array}{l}0.215 \\
(0.120)\end{array}$ & $\begin{array}{l}0.146 \\
(0.210)\end{array}$ & $\begin{array}{l}0.183 \\
(0.184)\end{array}$ & $\begin{array}{l}0.182 \\
(0.359)\end{array}$ & $\begin{array}{l}0.138 \\
(0.438)\end{array}$ \\
\hline $\begin{array}{l}\text { GRP } \\
\text { growth }\end{array}$ & $\begin{array}{l}6.577 * * * \\
(0.000)\end{array}$ & $\begin{array}{l}2.981 * * \\
(0.030)\end{array}$ & $\begin{array}{l}6.837 * * * \\
(0.000)\end{array}$ & $\begin{array}{l}2.753 * * \\
(0.027)\end{array}$ & $\begin{array}{l}6.494 * * * \\
(0.000)\end{array}$ & $\begin{array}{l}3.069 * * \\
(0.021)\end{array}$ & $\begin{array}{l}4.961 * * * \\
(0.000)\end{array}$ & $\begin{array}{l}2.192 * * \\
(0.014)\end{array}$ \\
\hline $\begin{array}{l}\text { Popula- } \\
\text { tion }\end{array}$ & $\begin{array}{l}-0.572 * \\
(0.078)\end{array}$ & $\begin{array}{c}-0.324 \\
(0.190)\end{array}$ & $\begin{array}{l}-0.624 * * \\
(0.045)\end{array}$ & $\begin{array}{l}-0.267 \\
(0.242)\end{array}$ & $\begin{array}{l}-0.700^{* *} \\
(0.046)\end{array}$ & $\begin{array}{l}-0.357 \\
(0.183)\end{array}$ & $\begin{array}{l}-0.680 \\
(0.110)\end{array}$ & $\begin{array}{l}-0.263 \\
(0.276)\end{array}$ \\
\hline $\begin{array}{l}\text { Vote share } \\
\text { for the } \\
\text { UR*Gini } \\
\text { ag enter- } \\
\text { prises }\end{array}$ & & & $\begin{array}{l}1.012 \\
(0.576)\end{array}$ & $\begin{array}{l}-2.113 \\
(0.219)\end{array}$ & & & $\begin{array}{l}0.471 \\
(0.801)\end{array}$ & $\begin{array}{l}-2.466 \\
(0.167)\end{array}$ \\
\hline $\begin{array}{l}\text { Number } \\
\text { of } \\
\text { instru- } \\
\text { ments/ } \\
\text { Hansen } \\
\text { overID } \\
\text { test }\end{array}$ & $43 / 0.127$ & $43 / 0.482$ & $43 / 0.160$ & $43 / 0.495$ & $44 / 0.127$ & $44 / 0.530$ & $42 / 0.064$ & $42 / 0.290$ \\
\hline $\operatorname{AR}(1)^{1}$ & 0.004 & 0.270 & 0.003 & 0.256 & 0.006 & 0.226 & 0.019 & 0.199 \\
\hline $\operatorname{AR}(4)$ & 0.400 & 0.300 & 0.378 & 0.398 & 0.337 & 0.296 & 0.256 & 0.408 \\
\hline
\end{tabular}




\section{Appendix 3: (continued)}

\begin{tabular}{|c|c|c|c|c|c|c|c|c|}
\hline \multirow[t]{2}{*}{ Variables } & \multicolumn{4}{|c|}{ (GMM DPM) } & \multicolumn{4}{|c|}{ (GMM DPM with IV) } \\
\hline & Federal & Regional & Federal & Regional & Federal & Regional & Federal & Regional \\
\hline $\begin{array}{l}\text { IV for } \\
\text { vote } \\
\text { share } \\
\text { for the } \\
\text { UR }\end{array}$ & No & No & No & No & Yes $^{2}$ & Yes & Yes & Yes \\
\hline $\bar{N}$ & 390 & 390 & 390 & 390 & 390 & 390 & 390 & 390 \\
\hline
\end{tabular}

$p$-values are reported in brackets

*Significant at 0.1 ; **significant at $0.05 ; * * *$ significant at 0.01

${ }^{1} \mathrm{AR}(2)$ and $\mathrm{AR}(3)$ test is not available because of missing observations during 2011

${ }^{2} \mathrm{As}$ an IV, we use vote share for the communist party in the previous electoral cycle

\section{References}

Albertus, M. 2015. The role of subnational politicians in distributive politics: Political bias in Venezuela's land reform under Chávez. Comparative Political Studies 48(13): 1667-1710. https://doi. org/10.1177/0010414015600457.

Arellano, M., and S. Bond. 1991. Some tests of specification for panel data: Monte Carlo evidence and an application to employment equations. The Review of Economic Studies 58(2): 277. https://doi. org/10.2307/2297968.

Aytaç, S.E. 2014. Distributive politics in a multiparty system: The conditional cash transfer program in Turkey. Comparative Political Studies 47(9): 1211-1237. https://doi.org/10.1177/0010414013495357.

Baland, B.J., and J.A. Robinson. 2018. Land and power: Theory and evidence from Chile. The American Economic Review 98(5): 1737-1765.

Bardhan, P., and D. Mookherjee. 2000. Capture and governance at local and national levels. American Economic Review 90(1996): 135-139.

Bardhan, P., and D. Mookherjee. 2006. Decentralisation and accountability in infrastructure delivery in developing countries. The Economic Journal 116: 101-127.

Becker, G.S. 1983. A theory of competition among pressure groups for political influence. The Quarterly Journal of Economics 98(3): 371-400.

Becker, G.S. 1985. Public policies, pressure groups, and dead weight costs. Journal of Public Economics 28: 329-347.

Besley, T., and R. Burgess. 2002. The political economy of government responsiveness: Theory and evidence from India. The Quarterly Journal of Economics 117: 1415-1451.

Blundell, R., and S. Bond. 1998. Initial conditions and moment restrictions in dynamic panel data models. Journal of Econometrics 87(1): 115-143.

Brusco, V., M. Nazareno, and S.C. Stokes. 2004. Vote buying in Argentina. Latin American Research Review 39(2): 66-88.

Chubb, J. 1982. Patronage, power, and poverty in Southern Italy. New York: Cambridge University Press.

Cox, G. 1987. Electoral equilibrium under alternative voting institutions. American Journal of Political Science 31(1): 82-108.

Cox, G. 1990. Centripetal and centrifugal incentives in electoral systems. American Journal of Political Science 34(4): 903-935.

Cox, G., and M. McCubbins. 1986. Electoral politics as a redistributive game. The Journal of Politics 48(2): 370-389.

Dahlberg, M., and E. Johansson. 2002. On the vote-purchasing behavior of incumbent governments. American Political Science Review 96(1): 27-40.

Dixit, A., and J. Londregan. 1996. The determinants of success of special interests in redistributive politics. The Journal of Politics 58(4): 1132-1155. 
Dixit, A., and J. Londregan. 1998. Fiscal federalism and redistributive politics. Journal of Public Economics 68(2): 153-180.

Enikolopov, R., V. Korovkin, M. Petrova, K. Sonin, and A. Zakharov. 2013. Field experiment estimate of electoral fraud in Russian parliamentary elections. Proceedings of the National Academy of Sciences of the United States of America 110: 448-452.

Frumina, V. 2016. Problemy predostavleniya subsidiy iz federal'nogo biudzheta sub'ektam Rossiyskoy Federatsyi. Finansy i Banki 5: 63-67.

Frye, T. 2002. Capture or exchange? Business lobbying in Russia. Europe-Asia Studies 54(7): 1017-1036.

Frye, T., O.J. Reuter, and D. Szakonyi. 2018. Hitting them with carrots: Voter intimidation and vote buying in Russia. British Journal of Political Science 49: 1-25.

Golosov, G.V. 2014. The territorial genealogies of Russia's political parties and the transferability of political machines. Post-Soviet Affairs 30(6): 464-480.

Gottlieb, J. 2017. Explaining variation in broker strategies: A ab-in-the-field experiment in Senegal. Comparative Political Studies 50(11): 1556-1592.

Government of Russia. 2004. O raspredelenii dotatsyy na vyravnivaniye biudzhetnoy obespechennosti subyekta Rossiyskoy Federatsyi.

Govorun, A., I. Marques, and W. Pyle. 2016. The political roots of intermediated lobbying: Evidence from Russian enterprises and business associations. Business and Politics 18(4): 395-433.

Grossman, G., and E. Helpman. 2001. Special interest politics. Cambridge, MA: MIT Press.

Grossman, G.M., and E. Helpman. 1996. Electoral competition and special interest politics. The Review of Economic Studies 63(2): 265.

Guriev, S., and E. Vakulenko. 2015. Breaking out of poverty traps: Internal migration and interregional convergence in Russia. Journal of Comparative Economics 43(3): 633-649. https://doi. org/10.1016/j.jce.2015.02.002.

Guriev, S., E. Yakovlev, and E. Zhuravskaya. 2010. Interest group politics in a federation. Journal of Public Economics 94(9-10): 730-748.

Hansen, J. 1991. Gaining access: Congress and the farm lobby. Chicago: The University of Chicago Press.

Hertel-Fernandez, A. 2016. How employers recruit their workers into politics-And why political scientists should care. Perspectives on Politics 14(2): 410-421.

Hiskey, J. 2003. Demand-based development and local electoral environments in Mexico. Comparative Politics 36(1): 41-59.

Holland, E.C. 2016. Economic development and subsidies in the North Caucasus. Problems of Post-Communism 63(1): 50-61.

Horowitz, J. 2016. The ethnic logic of campaign strategy in diverse societies: Theory and evidence from Kenya. Comparative Political Studies 49(3): 324-356. https://doi.org/10.1177/0010414015617963.

Jarocińska, E. 2010. Intergovernmental grants in Russia. Economics of Transition 18(2): 405-427.

Konitzer-Smirnov, A. 2005. Serving different masters: Regional executives and accountability in Ukraine and Russia. Europe-Asia Studies 33(12): 951-958.

Lerman, Z. 2017. Privatisation and changing farm structure in the Commonwealth of Independent States. In The Eurasian wheat belt and food security, ed. S.G.Y. Paloma et al., 15-33. Switzerland: Springer.

Lindbeck, A., and J. Weibull. 1987. Balanced-budget redistribution as the outcome of political competition. Public Choice 52(3): 273-297.

Magaloni, B. 2008. Credible power-sharing and the longevity of authoritarian rule. Comparative Political Studies 41(4/5): 1-27.

Mares, I., and L.E. Young. 2018. The core voter's curse: Clientelistic threats and promises in Hungarian elections. Comparative Political Studies 51(11): 1441-1471.

Marques, I., E. Nazrullaeva, and A. Yakovlev. 2016. Substituting distribution for growth: The political logic of intergovernmental transfers in the Russian Federation. Economics and Politics 28(1): 23-54.

Myerson, R.B. 1993. Incentives to cultivate favored minorities under alternative electoral systems. The American Political Science Review 87(4): 856-869.

Nye, J.V.C., and O. Vasilyeva. 2015. When does local political competition lead to more public goods? Evidence from Russian regions. Journal of Comparative Economics 43(3): 650-676. https://doi. org/10.1016/j.jce.2015.03.001.

OECD. 2017. Agricultural policy monitoring and evaluation 2017. Paris. http://www.oecd-ilibrary.org/ docserver/download/5117061e.pdf?expires $=1512141632 \& i d=$ id\&accname $=$ oid009539\&check sum $=$ 7E794D576AA021D943C9EA8D4C47FF1F\%0Ahttp://www.oecd-ilibrary.org/agricultur e-and-food/agricultural-policy-monitoring-and-evaluation-2017_agr_po. 
Olson, M. 1965. The logic of collective action: Public goods and the theory of groups. Harvard: Havard University Press.

Panov, P., and C. Ross. 2013. Sub-national elections in Russia: Variations in United Russia's domination of regional assemblies. Europe-Asia Studies 65(4): 737-752.

Parker, E., and J. Thornton. 2007. Fiscal centralisation and decentralisation in Russia and China. Comparative Economic Studies 49(4): 514-542.

Petrikov, A. 2016. O napravleniyah gosudarstvennoy podderzhki selskogo hoziaystva posle vstupleniya Rossii v WTO. In Sistema gosudarstvennoy podderzhki selskogo hoziaystva $v$ usloviyah chlenstva Rossii v WTO, ed. S. Kiselev, 13-20. Moscow: Economic Faculty, Moscow State University.

Ponomareva, M., and E. Zhuravskaya. 2004. Federal tax arrears in Russia: Liquidity problems, federal redistribution or regional resistance? Economics of Transition 12(3): 373-398.

Popov, V. 2004. Fiscal federalism in Russia: Rules versus electoral politics. Comparative Economic Studies 46: 515-541.

Potter, C., and J. Burney. 2002. Agricultural multifunctionality in the WTO-Legitimate non-trade concern or disguised protectionism? Journal of Rural Studies 18: 35-47.

Reuter, O.J. 2010. The politics of dominant party formation: United Russia and Russia's Governors. Europe-Asia Studies 62(2): 293-327.

Reuter, O.J., Buckley, N., Shubenkova, A., and G. Garifullina. 2016. Local elections in authoritarian regimes: An elite-based theory with evidence from Russian mayoral elections. Comparative Political Studies 49(5): 662-697. https://doi.org/10.1177/0010414015626439.

Reuter, O.J., and T.F. Remington. 2009. Dominant party regimes and the commitment problem: The case of United Russia. Comparative Political Studies 42(4): 501-526.

Reuter, O.J., and G.B. Robertson. 2012. Subnational appointments in authoritarian regimes: Evidence from russian gubernatorial appointments. The Journal of Politics 74(4): 1023-1037.

Robertson, G. 2010. The politics of protest in hybrid regimes: Managing dissent in post-communist Russia. Cambridge, MA: Cambridge University Press.

Roodman, D. 2009. How to do xtabond2: An introduction to difference and system GMM in Stata. The Stata Journal 59(1): 86-136.

Ross, C. 2010. Federalism and inter-governmental relations in Russia. Journal of Communist Studies and Transition Politics 26(2): 165-187.

RosStat. 2017. Raspredeleniye zaniatogo naseleniaya po vidam ekonomicheskoy deyatelnosti na osnovnoy rabote. Moscow.

Rueda, M.R. 2017. Small aggregates, big manipulation: Vote buying enforcement and collective monitoring. American Journal of Political Science 61(1): 163-177.

Schoors, K., and L. Weill. 2017. Russia's 1999-2000 election cycle and the politics-banking interface BOFIT discussion papers. Helsinki. BOFIT Discussion Papers.

Shagaida, N., V. Uzun, E. Gataulina, and R. Yanbykh. 2015. Otsenka urovnia podderzhki selskogo hoziaystva $i$ razrabotka mehanizmov sinhronizatsyi federalnoy $i$ regionalnyh agrarnyh politik $v$ usloviyah chlenstva Rossii v VTO. Moscow.

Shepsle, K., and B. Weingast. 1981. Political preferences for the pork barrel: A generalization. American Journal of Political Science 25(1): 96-111.

Slider, D. 2010. How united is United Russia? Regional sources of intra-party conflict. Journal of Communist Studies and Transition Politics 26(2): 257-275.

State Statistics Committee of Russia. 2018. Average nominal salary of employees of all types of organizations by economic activities.

Stokes, S.C. 2005. Perverse accountability: A formal model of machine politics with evidence from Argentina. The American Political Science Review 99(3): 315-325.

Stokes, S.C. 2007. Political clientilism. In The Oxford handbook of comparative politics, ed. C. Boix and S.C. Stokes, 604-627. New York, NY: Oxford University Press.

Treisman, D. 1998. Fiscal redistribution in a fragile federation: Moscow and the regions in 1994. British Journal of Political Science 28(01): 185-222.

Uzun, V. 2005. Large and small business in Russian agriculture: Adaptation to market. Comparative Economic Studies 47(1): 85-100.

Uzun, V. 2015. Printsypy formirovaniya i rashodovaniya agrarnogo biudzheta v Rossii, USA i ES. Agrarnaya Ekonomicheskaya Politika 32-41.

Uzun, V., N. Shagayda, R. Yanbykh, V. Saraykin, and E. Gataulina. 2016. Prakticheskiye rekomendatsii po sovershenstvovaniyu sistemy podderzhki selskogo hoziaystva v usloviyah chlenstva Rossii v 
WTO. In Sistema gosudarstvennoy podderzhki selskogo hoziaystva $v$ usloviyah chlenstva Rossii $v$ WTO, ed. S. Kiselev, 102-118. Moscow: Economic Faculty, Moscow State University.

Uzun, V. 2017. Ogranicheniye razmera subsidiy odnomy sel'hozproizvoditeliu: Neobhodimost', mehanizmy, posledstviya. Agrarnaya politika: Problemy i resheniya 11: 12-31.

Uzun, V., and Z. Lerman. 2017. Outcomes of Agrarian reform in Russia. In The Eurasian wheat belt and food security, ed. S. Paloma et al., 81-102. Switzerland: Springer.

Visser, O., N. Mamonova, and M. Spoor. 2012. Oligarchs, megafarms and land reserves: Understanding land grabbing in Russia. Journal of Peasant Studies 39(3-4): 899-931.

Weingast, B.R. 2009. Second generation fiscal federalism: The implications of fiscal incentives. Journal of Urban Economics 65(3): 279-293.

Wilson, J., and E. Banfield. 1963. City politics. Cambridge, MA: Harvard University Press.

Windmeijer, F. 2005. A finite sample correction for the variance of linear efficient two-step GMM estimators. Journal of Econometrics 126(1): 25-51.

Wooldridge, J. 2009. Econometric analysis of cross section and panel data. Cambridge, MA: MIT Press.

Zhuravskaya, E. 2010. Federalism in Russia. http://www.cefir.ru/papers/WP141.pdf.

Publisher's Note Springer Nature remains neutral with regard to jurisdictional claims in published maps and institutional affiliations. 